\title{
A regional model of interprofessional education
}

This article was published in the following Dove Press journal:

Advances in Medical Education and Practice

7 January $201 \mathrm{I}$

Number of times this article has been viewed

\section{Maria Olenick' \\ Edward Foote' \\ Patricia Vanston' \\ John Szarek' \\ Zachary Vaskalis' \\ Mary Jane Dimattio ${ }^{2}$ \\ Raymond A Smego J ${ }^{2}$ \\ 'The Commonwealth Medical College, Scranton, PA, USA; Nesbitt College of Pharmacy and Nursing, Wilkes University, Wilkes-Barre, PA, USA; \\ ${ }^{2}$ University of Scranton, Scranton, PA, USA}

Correspondence: Maria Olenick Clinical Skills Center, 50 I Vine St, Scranton, PA 18509, USA

Tel + I 5705049076

Fax + I 5705049615

Email molenick@tcmedc.org
Abstract: This paper describes the innovative features of the first regional model of interprofessional education (IPE) in the US, developed by The Commonwealth Medical College, Scranton, PA, USA, as a new, independent, community-based medical school in northeastern Pennsylvania. Essential educational components include collaborative care seminars, interprofessional sessions, simulations, live web-based seminars and newly innovative virtual environment interactive exercises. All of these elements are being integrated into the curricula of 14 undergraduate and allied professional schools, and three graduate medical education programs located in the region. Activities incorporate simulation, standardized patients, student leadership, and faculty and student facilitation. As this new regional model of interprofessional education is fully implemented, its impact will be assessed using both quantitative and qualitative outcomes measurements. Appropriate ongoing modifications to the model will be made to ensure improvement and further applicability to collaborative learning.

Keywords: interprofessional education, regional model, medical education

\section{Introduction}

The Center for Advancement of Interprofessional Education ${ }^{1}$ defines IPE as a teaching and learning process that fosters collaborative work between two or more professions. It occurs when students learn with, from, and about one another. IPE is a proven, beneficial approach to collaborative learning that is frequently promulgated but not always successfully implemented. Typically, IPE involves different health care professions within the confines of a single-site, academic health sciences center. Substantive participation in IPE among geographically distinct institutions poses additional obstacles and challenges. Herein, we describe a new regional model of IPE which brings together multiple and geographically disparate stakeholders including undergraduate pre-health and health professional programs, and postgraduate medical education programs, and which is applicable to other academic institutions with a distributive model of medical education.

\section{Institutional background}

The Commonwealth Medical College (TCMC), the United States' newest allopathic medical school, is a private, independent (ie, not part of a university structure), community-based medical school with three regional campuses in Scranton, Wilkes-Barre, and Williamsport, Pennsylvania. Its mission is to "educate aspiring physicians and scientists to serve society using a community-based, patient-centered, interprofessional and evidence-based model of education that is committed to inclusion, 
promotes discovery and utilizes innovative techniques". In northeastern Pennsylvania, health profession students complete their education and clinical training in the various hospitals, clinics and physicians' offices of the region. Despite their close proximity, these students and their parent institutions rarely participate in collaborative educational exercises. TCMC has begun to address this gap through the creation of the country's first regional model for IPE, the Northeast Pennsylvania (NEPA) Interprofessional Education Coalition (IPEC), a collaborative endeavor that involves 17 undergraduate, postgraduate and health profession institutions or programs spread out among several large counties in northeastern Pennsylvania ${ }^{2}$ (Table 1). The following are numbers of regional programs and approximate annual participants in NEPA IPEC member institutions: Nursing (8 programs: Licensed Practical Nurse - 35 participants each; Registered Nurse - 40-50 each); nurse's aide (2 programs: 30-50 each); occupational therapy (3 programs: 30-50 each); physical therapy (3 programs: 30-50 each); physician assistant (4 programs: 30-50 each); pharmacy (1 program: 30-50); speech language pathology (1 program: 30-50); nutrition (1 program: 30$)$; social work (2 programs: 30 each); health education (1 program: 30 ); emergency medical services (3 programs: 30-40 each); dental hygiene (1 program: 30); surgical technology (2 programs: 30 each); vascular technology (1 program: 20); diagnostic medical sonography (1 program: 30); echocardiography (1 program: 30); phlebotomy (1 program: 30$)$; pharmacy technology (1 program: 30$)$; respiratory therapy (1 program: 30$)$; radiation technology (1 program: 30$)$; medical imaging (1 program: 30); biomedical engineering (3 programs 30-40 each); counseling and human services ( 2 programs: 30 each); community health education ( 1 program: 20 ); exercise science ( 1 program: 20-30).

\section{The implementation}

The logistics of initially contacting and bringing together potential educational participants for IPE from within a 16-county area were daunting to consider. However, the widespread local publicity about the College and public awareness of the huge educational and health-related impact that TCMC would have on this region helped tremendously in facilitating our mission. Furthermore, there was strong support for the development of a medical school among institutions of higher learning in the region. One of the authors (MO) made direct telephone contact with these institutions and invited their participation on an IPE advisory council. The turnout at the first coalition meeting was sizeable, yet

Table I Northeastern Pennsylvania Interprofessional Education Coalition - The Commonwealth Medical College

\section{Participating institution \\ Misericordia University \\ King's College \\ Wilkes University \\ Marywood University}

The Commonwealth Medical College

Lackawanna College

Luzerne Community College

Lycoming College

Johnson College

University of Scranton

Pennsylvania College of Technology

East Stroudsburg University

Lock Haven University

Area Health Education Center, Keystone College

Wright Center for Graduate Medical Education

Internal Medicine Residency Program

Wyoming Valley Family Medicine

Residency Program

Williamsport Family Medicine

Residency Program

the mood of the group was tentative as individual members seemed uncertain of their precise role. Nevertheless, by the third meeting the group was transformed into a cohesive and interactive panel, and brainstorming turned productive. NEPA IPEC member institutions agreed to integrate IPE into their health professions educational curricula. The 
venue of coalition meetings has become rotational so that each member institution can host a meeting and "show off" their faculty and facilities, and this has optimized group buy-in and perceived ownership of the program. In March 2009, NEPA IPEC held its first annual IPE conference with national and international speakers and excellent regional attendance. The objective of this conference was to unite health professional educators, researchers and other stakeholders to achieve a unified understanding of what IPE means and to examine collaborative approaches to successful IPE implementation.

\section{Interprofessional educational components}

Interprofessional education learning objectives across the 4-year TCMC curriculum are shown in Table 2. The essentials of these objectives are to socialize health care students and professionals to work together, to help them develop mutual understanding and respect for various disciplines, and to impart collaborative practice competencies. Other schools involved in the NEPA IPEC have not yet established institutional curricular objectives of their own but they share in the TCMC IPE vision.

IPE educational components conducted to date include interprofessional panel discussions, simulation center activities, half-day collaborative-care seminars, and case-based interprofessional sessions and simulations. This academic year (2010) NEPA IPEC will develop synchronous webbased seminars (webinars) and newly innovative virtual environment interactive technologies, since these are increasingly being used to create modes of online learning, and are relevant for IPE. Educational elements of webinars will include the use of standardized and simulated standardized patients, intragroup and interprofessional discussions (with faculty and student group leaders as facilitators), and group and individual participant reflection. A select list of relevant topics includes patient-centered disease and wellness topics, Accreditation Council for Graduate Medical Education (ACGME) core competencies (eg, communication, professionalism), informatics, clinical skills training, cross-cultural competency, faith and spirituality, medical ethics, leadership and management skills assessment, death and dying, domestic violence, research methods and skills, medical errors, global health strategies, teambuilding, and quality improvement. ${ }^{3-10}$ A library of cases will be developed and recorded and will be used for discussion by interprofessional groups or as individual web-based tutorials. Web-based IPE will include a facilitator training program, e-learning materials and interprofessional team working skills workshops.

Our regional IPE network uses advanced technology to enhance collaboration over a broad geographic area. Technologic requirements include internet upgrade programming, wireless human patient simulators, and telemedicine capabilities in order to optimize standardized patient physical examination and student interactions. ${ }^{11,12}$ TCMC's Clinical Skills and Simulation Center was developed as a shared resource for health professional students in the area, and serves as valuable asset and venue for regional IPE.

Table 2 Interprofessional education (IPE) learning objectives across the 4-year curriculum - The Commonwealth Medical College

\begin{tabular}{|c|c|c|c|}
\hline Level I & Level 2 & Level 3 & Level 4 \\
\hline $\begin{array}{l}\text { I.I: Identify the roles, } \\
\text { contributions and expertise } \\
\text { of various health care professionals } \\
\text { in the delivery of health care } \\
\text { services to individuals, families } \\
\text { and communities. }\end{array}$ & $\begin{array}{l}\text { 2.I: Describe the roles, } \\
\text { contributions and expertise } \\
\text { of various health } \\
\text { care professionals in the } \\
\text { delivery of health care services } \\
\text { to individuals, families and } \\
\text { communities. }\end{array}$ & $\begin{array}{l}\text { 3.I:Analyze the roles, } \\
\text { contributions and expertise of } \\
\text { various health care professionals } \\
\text { in the delivery of health care } \\
\text { services to individuals, } \\
\text { families and communities. }\end{array}$ & $\begin{array}{l}\text { 4.I: Evaluate and assess the roles, } \\
\text { contributions and expertise of } \\
\text { various health care professionals } \\
\text { in the delivery of health care } \\
\text { services to individuals, families and } \\
\text { communities. }\end{array}$ \\
\hline $\begin{array}{l}\text { I.2: Participate in inter- } \\
\text { professional learning activities } \\
\text { and examine self attitudes } \\
\text { toward interprofessional } \\
\text { collaboration in health care. }\end{array}$ & $\begin{array}{l}\text { 2.2: Participate in, reflect on } \\
\text { and analyze inter-professional } \\
\text { learning activities including } \\
\text { identification of the benefits } \\
\text { and challenges of } \\
\text { interprofessional collaboration. }\end{array}$ & $\begin{array}{l}\text { 3.2: Participate in, reflect on } \\
\text { and synthesize interprofessional } \\
\text { experiences. }\end{array}$ & $\begin{array}{l}\text { 4.2: Demonstrate and support } \\
\text { respectful collaboration with other } \\
\text { members of the health care team, } \\
\text { health care recipients and society to } \\
\text { ensure optimal health and welfare of } \\
\text { individuals, families and communities. }\end{array}$ \\
\hline $\begin{array}{l}\text { I.3: Identify values and beliefs } \\
\text { of self in relation to medical } \\
\text { practice within diverse } \\
\text { interprofessional settings. }\end{array}$ & $\begin{array}{l}\text { 2.3: Describe and debate the } \\
\text { importance of collaboration } \\
\text { and communication with other } \\
\text { members of the health care } \\
\text { team, health care recipients and } \\
\text { society to ensure optimal health } \\
\text { and welfare of individuals, families } \\
\text { and communities. }\end{array}$ & $\begin{array}{l}\text { 3.3: Create interprofessional } \\
\text { relationships to maximize health } \\
\text { care team function. }\end{array}$ & $\begin{array}{l}\text { 4.3: Act consistently in providing } \\
\text { comprehensive, interprofessional, } \\
\text { patient-centered health care to } \\
\text { individuals, families and communities. }\end{array}$ \\
\hline
\end{tabular}


In the spring 2010, as part of NEPA IPEC's second annual IPE conference, more than 300 health professional students from the region participated in a collaborative-care seminar day. Disciplines included internal medicine, nursing, diagnostic imaging, pharmacy, paramedics, occupational therapy, nutritionists and physician assistant. Students were assigned to small groups (about 10-12 students) representing multiple professions. They worked through a case study which was facilitated by two faculty members of different health professions per group. The collaborative-care seminar took place concurrently at four separate locations and represented all 17 health education degree programs from our consortium.

Simulations offer another venue in which IPE components have been delivered at TCMC. For example, as part of the first-year neuroscience course students had to call a pharmacist to reconcile medications that their patient was taking. Faculty members from the Wilkes University Pharmacy program were on call to answer the student telephone inquiries when they came in. Students were required to present their patient to the pharmacist over the phone and discuss their patient's medication record. Additionally, this was an opportunity for the pharmacist to instruct the students about medication errors caused by sound-alike drug names. In Years 3 and 4, TCMC medical students will have an opportunity to work in a team with other health care professionals on the care of a simulated patient.

\section{Discussion}

As a new, community-based medical school with 3 regional campuses, TCMC is philosophically committed to developing a sustainable, embedded interprofessional module within its own integrated undergraduate health science curriculum, as well as within the curricula of health professional institutions in the region. The establishment of an institutional coalition to oversee IPE is an important aspect of our regional model. The NEPA IPEC has the objectives of exposure to different schools of thought, management of care via technology, networking and cultivation of global perspectives on health care delivery, and experience with novel educational approaches. Our varied curriculum comprises interprofessional experiences for students that reflect the six Institute of Medicine ${ }^{13}$ aims for health care. The innovation of our model lies in the extensive partnership/collaboration that has been established with 17 health sciences programs and institutions in the region to develop IPE capacity for (among others) students of medicine, nursing, pharmacy, occupational and physical therapy, clinical nutrition and social work, as well as family medicine and internal medicine residents (Table 1). Students from all of the participating NEPA IPEC programs are also included now as members so that they may contribute to future IPE success in this regional model of IPE delivery.

There are numerous academic and logistical challenges or barriers to IPE delivery. ${ }^{14}$ On a practical level, developing IPE activities around differing academic calendars and class scheduling can be time-consuming, but these issues are usually worked through at the NEPA IPEC meetings. Recruitment of faculty for IPE activities has been easy, as participating faculty generally volunteer their time (in fact, across institutions we typically have more interested faculty than small group facilitator slots). As for space for IPE activities, the venues of coalition meetings and activities are rotational so that member institutions have an opportunity to highlight their faculties and facilities; this also has the advantage of sharing some of the costs of IPE. Finally, the high-level buy-in of academic leadership within the regional coalition, from program directors to college and university deans/provosts, has brought a tremendous degree of commitment and stability.

Integrating a curriculum is a complex process, and it is understood and experienced differently by students and faculty. ${ }^{15}$ Curran et a ${ }^{16}$ explored attitudes of health sciences students towards interprofessional teamwork and IPE. Medical and nursing students reported less positive attitudes towards interprofessional teamwork than pharmacy and social work students. Nursing, pharmacy and social work students had significantly more positive attitudes towards IPE than medical students, and woman and senior undergraduates demonstrated more positive attitudes towards interprofessional teamwork and IPE. Students with IPE experience had more positive attitudes towards interprofessional teams than those who had not been exposed to IPE. Westberg and colleagues ${ }^{9}$ used standardized patient experiences with pharmacy, medical and nursing students whose professional roles were switched, and noted that pharmacy students gained a better perspective about the roles of other health professionals overall.

The clinical teamwork training inherent in our shared curriculum can increase interprofessional competence, defined as knowledge and understanding of their own and the other team members' professional roles, comprehension of communication and teamwork, and collaboration in taking care of patients;. ${ }^{16-22}$ In a team-based approach, IPE relies significantly on student leaders in helping guide their peers through the learning process. Hoffman and Harnish ${ }^{23}$ used an evidence-based review of the literature and a questionnaire administered to Canada's top student leaders and determined that student leadership is essential to the success of IPE 
because it enhances students' willingness to collaborate, and facilitates the long-term sustainability of IPE efforts.

Health sciences educators continue to debate the optimal timing for introducing IPE into the academic training of health professionals, although evidence-based IPE continues to be offered at increasingly early stages in students' professional development. Undergraduate health professions students are probably best molded early in their professional training, in order to minimize negative biases and perceptions. ${ }^{24}$ Mandatory participation in IPE for pre-health professional students can result in profound changes in attitudes, interests and professionalism. ${ }^{25}$ Even first-year undergraduate students can learn about teamwork and increase awareness about collaborative practice and care delivery. ${ }^{26}$

We have already started to assess the effectiveness of our regional, integrated IPE curricular model. A pilot study, conducted to determine attitudes toward IPE at the NEPA IPEC Collaborative Care Seminar event in spring 2010, found the opinions of both health care students and facilitators to be generally positive (Table 3 ), although there were differing

Table 3 Selected comments from health care students and facilitators on an IPE summit

\begin{tabular}{|c|c|c|}
\hline & Agree (\%) & $\begin{array}{l}\text { Strongly } \\
\text { agree (\%) }\end{array}$ \\
\hline \multicolumn{3}{|l|}{ Health care students } \\
\hline $\begin{array}{l}\text { The case-discussion approach } \\
\text { was an effective way to teach } \\
\text { interprofessional concepts. }\end{array}$ & 37.9 & 45.2 \\
\hline $\begin{array}{l}\text { The case-discussion revealed } \\
\text { new ideas on how to approach } \\
\text { patient care. }\end{array}$ & 32.4 & 42.9 \\
\hline $\begin{array}{l}\text { After attending the summit, } \\
\text { I have a greater understanding } \\
\text { of the role of other health care } \\
\text { professionals in the care of patients. }\end{array}$ & 33.9 & 49.1 \\
\hline $\begin{array}{l}\text { After attending the summit, } \\
\text { I have a greater appreciation for } \\
\text { my profession's role in the care } \\
\text { of patients. }\end{array}$ & 37.2 & 43.1 \\
\hline $\begin{array}{l}\text { After attending the summit, } \\
\text { I am able to identify gaps in } \\
\text { my understanding of the role } \\
\text { of other health care professionals. }\end{array}$ & 31.7 & 50.0 \\
\hline $\begin{array}{l}\text { I would recommend this summit } \\
\text { to other students. }\end{array}$ & 39.9 & 39.0 \\
\hline Overall, this program was effective. & 35.3 & 45.9 \\
\hline Facilitators & & \\
\hline Overall, this program was effective. & 63.0 & 33.3 \\
\hline $\begin{array}{l}\text { I found this summit to be } \\
\text { professionally rewarding. }\end{array}$ & 63.0 & 29.6 \\
\hline $\begin{array}{l}\text { I would participate as a facilitator } \\
\text { in future summits. }\end{array}$ & 85.2 & II.I \\
\hline
\end{tabular}

attitudes toward interprofessional teamwork and education among health professional students..$^{27}$ The consortium plans additional qualitative (eg, via phenomenologic methods of empiric and reflective inquiry including student/faculty surveys of attitudes towards IPE and interprofessional teamwork) and quantitative research. The latter will utilize several instruments that have been used to monitor changes in attitudes and perceptions of IPE by undergraduate students from various kinds of health and social care programs, such as the Readiness for Interprofessional Learning (RIPLS) Scale and the Interdisciplinary Education Perception Scale (IEPS). . $^{16,28-30}$

Dr Darrell Kirsch, President of the Association of American Medical Colleges (AAMC), has stated that interprofessional education and practice has been designated as a key strategic area that will be vital to the future culture of physicians. ${ }^{31} \mathrm{He}$ recommended that simulation center resources be shared by health professional education programs since these centers are relevant venues for integrating health care professional students, and shared facilities and resources lead to shared curricular activities, creating interprofessional learning experiences. Currently, TCMC shares its Clinical Skills and Simulation Center with a number of health professions programs: nursing and nurse anesthetist students from the University of Scranton; physician assistants from Marywood University; internal medicine residents from the Wright Center for Medical Education Residency Program; and biomedical engineering students from Johnson College; and regional pediatric professionals (ie, pediatricians, nurses, respiratory therapists, and so on). Simulation activities include student learning in the areas of standardized patient exercises, patient assessment, practice in cardiorespiratory arrest (code) situations, and procedural skills such as intubation, placement of epidural catheters, arterial lines and central lines, vaginal birthing, physiology labs using the biopak systems, and repair and maintenance of medical equipment such as defibrillators and intravenous pumps.

In summary, our new regional model of IPE brings together multiple and geographically disparate stakeholders including undergraduate pre-health and health professional programs, and postgraduate medical education programs. As this integrated curriculum is implemented, its impact will be assessed and documented using specific quantitative and qualitative outcome measurements. Appropriate ongoing modifications to the model will be made to ensure improvement and further applicability to patient-centered learning and patient safety. 


\section{Acknowledgment}

This paper was first presented in part at the Annual Meeting of the Association of American Medical Colleges (AAMC), Boston, November 6-11, 2009.

\section{Disclosure}

The authors disclose no conflicts of interest.

\section{References}

1. Centre for the Advancement of Interprofessional Education (CAIPE). Available from: http://www.caipe.org.uk/about-us/definingipe/?keywords=definition. Accessed 2009 Aug 18.

2. Northeast Pennsylvania Interprofessional Education Coalition (NEPA IPEC). Available from: http://nepaipec.friendlyfirm.com/home.html. Accessed 2008 Nov 13.

3. Brehm B, Breen P, Brown B, et al. An interdisciplinary approach to introducing professionalism. Am J Pharm Educ. 2006;70:81.

4. Gassert CA, Peay WJ, Mitchell JA. A model of interprofessional informatics education. Stud Health Technol Inform. 2006;122:149-152.

5. Kyrkjebø JM, Brattebø G, Smith-Strøm H. Improving patient safety by using interprofessional simulation training in health professional education. J Interprof Care. 2006;20:507-516.

6. Murphy ST, Censullo M, Cameron DD, Baigis JA. Improving crosscultural communication in health professions education. J Nurs Educ. 2007;46:367-372.

7. Sijstermans R, Jaspers MW, Bloemendaal PM, Schoonderwaldt EM. Training inter-physician communication using the Dynamic Patient Simulator. Int J Med Inform. 2007;76:336-343.

8. Varga-Atkins T, Cooper H. Developing e-learning for interprofessional education. J Telemed Telecare. 2005;11suppl 1:102-104.

9. Westberg SM, Adams J, Thiede K, Stratton TP, Bumgardner MA. An interprofessional activity using standardized patients. Am J Pharm Educ. 2006;15:34.

10. White JL. Introducing undergraduate students to global health challenges through web-based learning. Nurs Educ Perspect. 2005;26:157-162.

11. Weinstein RS, López AM, Barker GP, et al. Arizona Telemedicine Program Interprofessional Learning Center: facility design and curriculum development. J Interprof Care. 2007;21 suppl 2:51-63.

12. Daley LK, Spalla TL, Arndt MJ, Warnes AM. Videoconferencing and web-based conferencing to enhance learning communities. J Nurs Educ. 2008;47:78-81.

13. Institute of Medicine. Health Professions Education: A Bridge to Quality. 2003.

14. Gilbert JHV. Interprofessional learning and higher education structural barriers. J Interprof Care. 2005;1 suppl:87-106.

15. Muller JH, Jain S, Loeser H, Irby DM. Lessons learned about integrating a medical school curriculum: perceptions of students, faculty and curriculum leaders. Med Educ. 2008;42:778-785.
16. Curran VR, Sharpe D, Forristall J, Flynn K. Attitudes of health sciences students towards interprofessional teamwork and education. Learning in Social Health and Social Care. 2008;7:146-156.

17. Chakraborti C, Boonyasai RT, Wright SM, Kern DE. A systematic review of teamwork training interventions in medical student and resident education. J Gen Intern Med. 2008;23:846-853.

18. Furze J, Lohman H, Mu K. Impact of an interprofessional communitybased educational experience on students' perceptions of other health professions and older adults. J Allied Health. 2008;37:71-77.

19. Goelen G, de Clercq G, Huyghens L, Kerckhofs E. Measuring the effect of interprofessional problem-based learning on the attitudes of undergraduate health care students. Med Educ. 2006;40:555-561.

20. Hallin K, Kiessling A, Waldner A, Henriksson P. Active interprofessional education in a patient based setting increases perceived collaborative and professional competence. Med Teach. 2009;31:151-157.

21. Hammick M, Freeth D, Koppel I, Reeves S, Barr H. A best evidence systematic review of interprofessional education: BEME Guide no. 9. Med Teach. 2007;29:735-751.

22. Johnson AW, Potthoff SJ, Carranza L, Swenson HM, Platt CR, Rathbun JR. CLARION: a novel interprofessional approach to health care education. Acad Med. 2006;81:252-256.

23. Hoffman SJ \& Hamish D. The merit of mandatory interprofessional education for pre-health professional students. Med Teach. 2009;29:e235-e242.

24. Coster S, Norman I, Murrells T, et al. Interprofessional attitudes amongst undergraduate students in the health professions: A longitudinal questionnaire survey. Int J Nurs Stud. 2008;45:1667-1681.

25. Hoffman SJ, Harnish D. The merit of mandatory interprofessional education for pre-health professional students. Med Teach. 2007;29:e235-e242.

26. Cooper H, Spencer-Dawe E, McLean E. Beginning the process of teamwork: design, implementation and evaluation of an inter-professional education intervention for first year undergraduate students. $J$ Interprof Care. 2005;19:492-508.

27. Szarek J, Vaskalis Z, Dimattio MJ. Effects of a Specific interprofessional education experience on health sciences students attitudes toward interprofessional teamwork and education. International Meeting on Simulation in Healthcare (IMSH). Denver; Jan 2010.

28. Curran VR, Sharpe D, Forristall J, Flynn K. Student satisfaction and perceptions of small group process in case-based interprofessional learning. Med Teach. 2008;30:431-433.

29. McFadyen AK, Webster VS, Maclaren WM. The test-retest reliability of a revised version of the Readiness for Interprofessional Learning Scale (RIPLS). J Interprof Care. 2006;20:633-639.

30. McFadyen AK, Maclaren WM, Webster VS. The Interdisciplinary Education Perception Scale (IEPS): an alternative remodeled sub-scale structure and its reliability. $J$ Interprof Care. 2007;21:433-443.

31. Association of American Medical Colleges (AAMC). Available from: http://aamc.org/newsroom/reporter/may08/word.htm. Accessed 2010 Aug 12. 


\section{Appendix}

\section{Northeastern PA Interprofessional Education Coalition faculty membership}

1. Maria Olenick, Director, Clinical Skills \& Simulation Center, The Commonwealth Medical College, Scranton, PA (co-chair).

2. Dr John Szarek, Professor of Pharmacology, The Commonwealth Medical College, Scranton, PA.

3. Dr Raymond A. Smego, Jr., Associate Dean for Educational Development, The Commonwealth Medical College, Scranton, PA.

4. Dr Mark White, Assistant Professor of Epidemiology, The Commonwealth Medical College, Scranton, PA.

5. Dr Richard English, Associate Dean for Regional Development, The Commonwealth Medical College and Director, Wyoming Valley Family Medicine Residency Program, Wilkes-Barre, PA.

6. Dr Keith Schenberger, Associate Dean for Regional Development, The Commonwealth Medical College, Williamsport, PA.

7. Dr Gerald Tracy, Associate Dean for Regional Development, The Commonwealth Medical College, Scranton, PA.

8. Dr Edward Foote, Chair, Department of Pharmacy, Nesbitt College of Pharmacy and Nursing, Wilkes University, Wilkes-Barre, PA (co-chair).

9. Dr Jean Dyer, Dean, College of Health Sciences, Misericordia University, Wilkes-Barre, PA.

10. Dr Debra Pellegrino, Dean, Panuska College of Professional Studies, University of Scranton, Scranton, PA.

11. Dr Karen Arscott, Director, Physician Assistant Program, Marywood University, Scranton, PA.

12. Dr Mark Kilker, Dean, College of Health Sciences, East Stroudsburg University, East Stroudsburg, PA.
13. Dr Dana Clark, Vice President for Academic Affairs and Provost, Luzerne Community College, Wilkes-Barre, PA.

14. Dr Thomas Griffiths, Dean and Provost, Lycoming Community College, Williamsport, PA.

15. Dr Frances Feudale, Director, Physician Assistant Program, King's College, Wilkes-Barre, PA.

16. Michael Macedonia, Director of Paramedic Training, Lackawanna College, Scranton, PA.

17. Sharon Waters, Dean of Health Sciences, Pennsylvania College of Technology, Williamsport, PA.

18. Vera Walline, Executive Director, Area Health Education Center (AHEC), Keystone College, LaPlume, PA.

19. Dr Arjinder Sethi, Associate Program Director, Scranton Temple Internal Medicine Residency Program, Scranton, PA.

20. Dr MaryAnn Merrigan, Chairperson, Department of Nursing, Wilkes University, Wilkes Barre, PA.

21. Dr Diane Haleem, Director of Nursing Program, Marywood University, Scranton, PA.

22. Dr Marian Farrell, Department of Nursing, University of Scranton, Scranton, PA.

23. Wendy Manetti, Department of Nursing, Marywood University, Scranton, PA.

24. Diane Easton, Physician Assistant Program Faculty, King's College, Wilkes Barre, PA.

25. Patricia Vanston, Assistant Dean for Continuing Education, The Commonwealth Medical College, Scranton, PA.

26. Carol Chaykosky, Area Health Education Center (AHEC), Keystone College, LaPlume, PA.
Advances in Medical Education and Practice

\section{Publish your work in this journal}

Advances in Medical Education and Practice is an international, peerreviewed, open access journal that aims to present and publish research on Medical Education covering medical, dental, nursing and allied healthcare professional education. The journal covers undergraduate education, postgraduate training and continuing medical education

\section{Dovepress}

including emerging trends and innovative models linking education, research, and healthcare services. The manuscript management system is completely online and includes a very quick and fair peer-review system. Visit http://www.dovepress.com/testimonials.php to read real quotes from published authors. 